Physical Geography; Cartography; Geographic Information Systems \& Spatial Planing

\title{
ASSESSMENT OF THE WATER QUALITY OF THE SERAVA RIVER BASED ON SOME PHYSICAL AND CHEMICAL PARAMETERS
}

DOI: http://dx.doi.org/10.18509/GBP.2016.08

UDC: 502.175:502.51(497.711:282)

\author{
Dr. Kole Pavlov \\ Josip Broz Tito High School - Skopje, Republic of Macedonia
}

\begin{abstract}
The Serava River springs of Mount Skopska Crna Gora at an altitude of 1,270 meters. Its confluence to Vardar River is located in the capital town of Macedonia-Skopje at 243 meters above sea level. The length of Serava River is 21 kilometers whose basin covers an area of $67 \mathrm{~km}^{2}$. It belongs to the group of small streams with a stable flow whose quality has not been subjected to regular monitoring by the competent institutions in the country. The significance of the water quality of this water flow is seen in the fact that his potential is intensively used for irrigation of vegetable crops in the area of the settlements Radishani and Butel. Task analysis of water quality that were undertaken in 2009/2010, have demonstrated exceeding the maximum allowable concentrations of accuracy in some indicators such as heavy metals, which emphasize the anthropogenic impact on water flow and simultaneously alert some appropriate measures to be taken against the water pollution.
\end{abstract}

Key words: Serava River, water pollution, water quality, heavy metals, etc. INTRODUCTION

The Serava River springs of Mount Skopska Crna Gora at an altitude of 1,270 meters. Its confluence to Vardar River is located in the capital town in Macedonia- Skopje at 243 meters above sea level. The significance of the water quality of the water flow is seen in the fact that its potential extensively used for irrigation of vegetable crops in the area of the settlements: Ljubanci, Radishani and Butel. It is the only surface water flow in the Municipality of Butel. At the same time is the biggest recipient of industrial waste water and municipal water, but also the largest donor of irrigation water in the municipality. Numerous natural and anthropogenic factors undoubtedly change the water quality of the river Serava in Skopje Basin, which brings significant concentrations of pollutants in recipient age, and it affects the deterioration of its waters. Water quality of the river Serava is not subjected to regular monitoring by the merits institutions in the country and therefore spontaneously occurred the need for systematic assessment of the water quality of this small tributary of the Vardar River in Skopje Basin, but probably with a huge and significant impact on the quality of the recipient. Studied in this paper were the waters of Serava River in Skopje which were monitored before the inflow into the river Vardar (Sample point, fig. 1). The assessment of the water quality was based on 10 indicators of basic physical and chemical analysis and 8 heavy metals as a criterion for quality. The main objective of the paper is to detect the level of contamination of the water in accordance with the prescribed limit values in the Decree on categorization of water in R. Macedonia. The secondary objective of the research is to assess their value in use for irrigation, and to identify natural and anthropogenic sources of pollution. 


\section{STUDY AREA}

The course of Serava River is located in the north of Skopje Basin, covering parts of southern and southwestern exposures of Skopska Crna Gora. Serava River was created after compiling of several smaller streams in the spring area as: Ljubanska River, Poboshka River, Turchevska River, Small River and Ljubotenska River (fig. 1). The main spring is considered to be the one below the top of Pupljak in Skopska Crna Gora at an altitude of 1,270 meters and flows into Vardar in Skopje at an altitude of 243 meters. The length of Serava River is 21 kilometers and the catchment area covers an area of $67 \mathrm{~km}^{2}$. The water management of Serava is used only in its springs, upper and middle reaches. The drainage basin of Serava administratively belongs to the municipality of Butel. The human impact on the waters in the municipality is made by the existing population which in the last census is counted to be 36154 inhabitants, with a population density of 594 inhabitants $/ \mathrm{km}^{2}$. Hypsometrically, $91 \%$ of the population is settled in the plain and hills up to 500 meters above sea level in the municipality so, the middle and lower parts of the watershed are with a largest pollution of the water. The population in the municipality of Butel is settled in 8 settlements such as: Skopje-Sever, Butel I, Butel II, Radishani, Vizbegovo, the Ljuboten's Road, Ljubanci and Ljuboten.

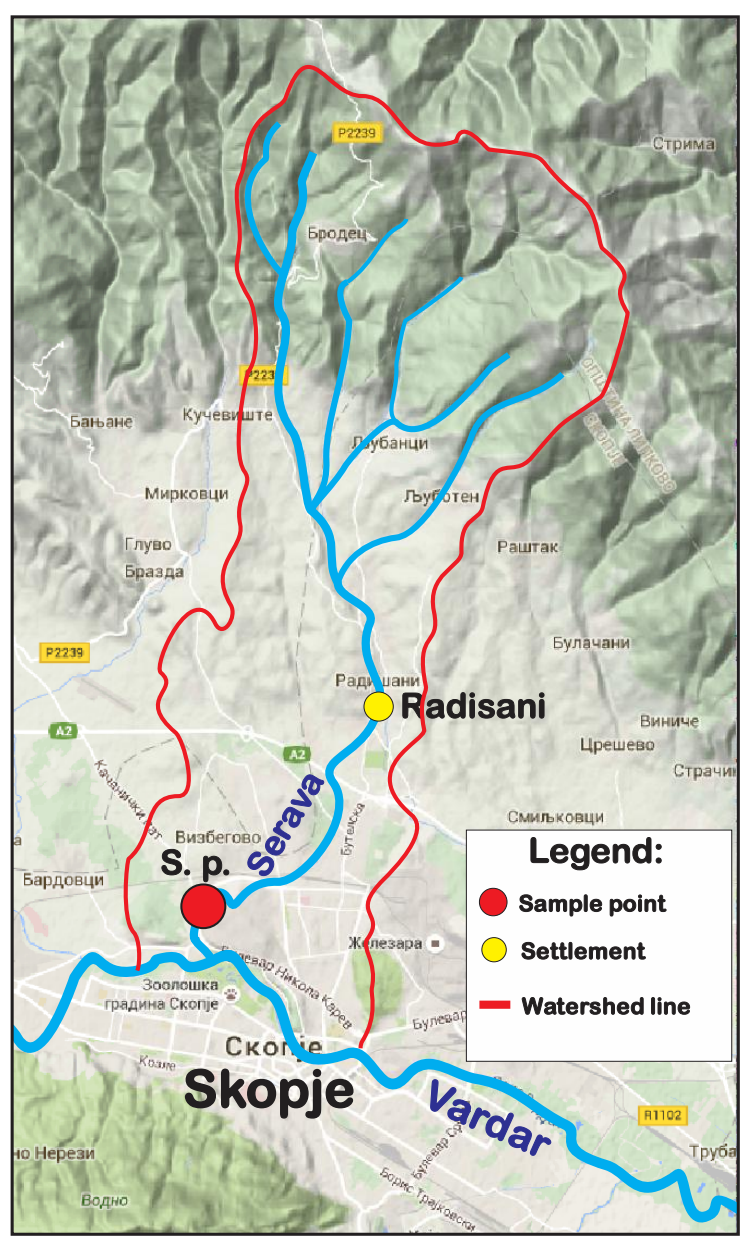

Figure 1. The Drainage Basin of Serava River 


\section{METHODS AND MATERIALS}

With the intention to objectively detect the pollution of the waters of Serava River, over the period of 12 months from September 2009 to August 2010, was firstly selected a monitoring point for measuring the quality assessment and the monitoring was conducted at a frequency of analyzed samples once a month. The monitoring point on Serava River was chosen before its confluence, in order to assess the impact by the population and by the industrial facilities that perform on the watercourse. (Sample point, fig. 1). Sampling is implemented according to the ISO 5667. Water samples were collected in polyethylene bottles previously washed with hydrochloric acid and rinsed out with abundant-distilled water in the laboratory and with abundant river water before collection. Some parameters were measured on the field such as: $\mathrm{pH}$, conductivity, $\mathrm{DO}$, also oxygen fixation was made immediately and measured by Winkler method, $\mathrm{BOD}_{5}$ and $\mathrm{COD}$ by $\mathrm{KMnO}_{4}$. Other parameters were analyzed in the laboratory of the Hydro meteorological Service. Hardness by EDTA titration, nutrients is determined by spectrophotometry using UVVIS Varian Carry 100. The heavy metals as parameters were analyzed in the laboratory of the Hydro meteorological Service. Heavy metals concentration of $\mathrm{Fe}, \mathrm{Mn}, \mathrm{Pb}, \mathrm{Cd}, \mathrm{Zn}$, $\mathrm{Cr}, \mathrm{Ni}, \mathrm{Cu}$ were determined by atomic absorption spectrometry using Varian 220 by graphite furnace and flame technique. As methods for determination of these parameters were used methods recommended by Standard Methods for the Examination of Water and Wastewater APHA, EPA, and EN/ISO methods. Water quality assessment was based on Macedonian regulation for classification of water quality [1].

\section{RESULTS AND DISCUSSION}

Table 1. Characteristics of the major physical-chemical analysis on the waters of Serava River

\begin{tabular}{llllllllllll}
\hline & \multicolumn{10}{c}{ PARAMETERS } \\
\hline Month & $\begin{array}{l}\text { Colour } \\
\text { (Pt-Co) }\end{array}$ & $\begin{array}{l}\text { Turbidity } \\
\text { (NTU) }\end{array}$ & $\mathbf{p H}$ & $\begin{array}{l}\text { Susp. } \\
\text { Mat. }\end{array}$ & $\begin{array}{l}\text { Ammonia } \\
\text { (NH4) }\end{array}$ & NO3 & NO2 & O2 & BOD & COD \\
\hline sep./2009 & 3,20 & 16,00 & 7,70 & 18,00 & 4,28 & 0,36 & 0,50 & 25,42 & 13,50 & 22,09 \\
\hline okt./2009 & 8,30 & 30,00 & 7,81 & 32,00 & 3,26 & 3,83 & 0,23 & 26,20 & 6,43 & 20,27 \\
\hline nov./2009 & 6,80 & 27,00 & 7,79 & 29,00 & 2,57 & 3,21 & 0,14 & 25,86 & 11,05 & 13,95 \\
\hline dec./2009 & 6,80 & 25,00 & 7,92 & 29,00 & 1,38 & 3,31 & 0,09 & 25,74 & 7,53 & 15,80 \\
\hline jan./2010 & 6,60 & 14,00 & 7,98 & 17,00 & 1,47 & 3,33 & 0,06 & 25,82 & 10,71 & 8,97 \\
\hline feb./2010 & 6,50 & 23,00 & 7,96 & 25,00 & 1,28 & 3,65 & 0,06 & 27,30 & 9,64 & 13,12 \\
\hline mar./2010 & 5,60 & 70,00 & 7,80 & 56,00 & 1,12 & 2,49 & 0,08 & 27,92 & 15,27 & 23,39 \\
\hline apr./2010 & 9,70 & 64,00 & 7,69 & 66,00 & 0,99 & 1,65 & 0,06 & 20,90 & 8,93 & 32,24 \\
\hline may/2010 & 5,60 & 13,00 & 7,79 & 14,00 & 1,22 & 2,84 & 0,19 & 12,28 & 7,05 & 12,49 \\
\hline jun./2010 & 6,50 & 12,00 & 7,75 & 14,00 & 1,44 & 3,70 & 0,30 & 12,10 & 7,61 & 14,22 \\
\hline jul./2010 & 8,20 & 6,00 & 7,59 & 8,00 & 2,74 & 6,72 & 0,62 & 7,06 & 6,71 & 18,85 \\
\hline avg./2010 & 8,20 & 5,00 & 7,36 & 7,00 & 2,84 & 7,30 & 0,82 & 9,48 & 7,55 & 17,65 \\
\hline $\mathbf{\Sigma}(\mathbf{a v e r a g e )}$ & $\mathbf{6 , 8 3}$ & $\mathbf{2 5 , 4 2}$ & $\mathbf{7 , 7 0}$ & $\mathbf{2 6 , 2 5}$ & $\mathbf{2 , 0 5}$ & $\mathbf{3 , 8 2}$ & $\mathbf{0 , 2 6}$ & $\mathbf{2 0 , 5 1}$ & $\mathbf{1 3 , 5 0}$ & $\mathbf{2 2 , 0 9}$ \\
\hline
\end{tabular}


Table 2. Concentrations of heavy metals in the waters of Serava River before confluence $(\mu \mathrm{g} / 1)$

\begin{tabular}{ccccccccc}
\hline Period & \multicolumn{7}{c}{ PARAMETERS } \\
\cline { 2 - 9 } & Fe & Mn & Pb & Zn & Cd & Cr & Ni & Cu \\
\hline sep./2009 & 28,00 & 49,00 & 7,23 & 6,00 & 0,90 & 1,60 & 0,63 & 4,90 \\
\hline okt./2009 & 158,00 & 101,00 & 1,56 & 8,00 & 0,26 & 1,36 & 1,87 & 4,84 \\
\hline nov./2009 & 15,00 & 48,00 & 6,22 & 0,20 & 0,21 & 0,67 & 0,64 & 0,58 \\
\hline dec./2009 & 56,00 & 74,00 & 6,67 & 89,00 & 1,74 & 1,47 & 1,58 & 6,97 \\
\hline jan./2010 & 38,00 & 37,00 & 2,24 & 37,00 & 0,04 & 0,56 & 4,95 & 6,10 \\
\hline feb./2010 & 46,00 & 23,00 & 2,09 & 39,00 & 0,05 & 1,30 & 0,88 & 5,86 \\
\hline mar./2010 & 94,00 & 37,00 & 1,04 & 30,00 & 0,05 & 0,24 & 1,33 & 5,06 \\
\hline apr./2010 & 94,00 & 37,00 & 2,01 & 30,00 & 0,18 & 0,58 & 0,73 & 13,37 \\
\hline may/2010 & 50,00 & 13,00 & 2,87 & 33,00 & 0,53 & 3,43 & 1,13 & 5,02 \\
\hline jun./2010 & 47,00 & 6,00 & 2,18 & 45,00 & 0,09 & 1,68 & 0,40 & 9,68 \\
\hline jul./2010 & 48,00 & 27,00 & 3,60 & 69,00 & 0,09 & 1,19 & 3,28 & 3,46 \\
\hline $\mathbf{\Sigma}$ average) & $\mathbf{6 1 , 2 7}$ & $\mathbf{4 1 , 0 9}$ & $\mathbf{3 , 4 3}$ & $\mathbf{3 5 , 1 1}$ & $\mathbf{0 , 3 8}$ & $\mathbf{1 , 2 8}$ & $\mathbf{1 , 5 8}$ & $\mathbf{5 , 9 9}$ \\
\hline
\end{tabular}

Among the parameters as criteria for water quality, 10 indicators of the basic physical and chemical analysis werw examinated (tab. 1) and 8 heavy metals (tab. 2; fig. 3).

Fugure 2. Indicators of the basic physic-chemical analysis on the waters of Serava River (the color match with the quality)

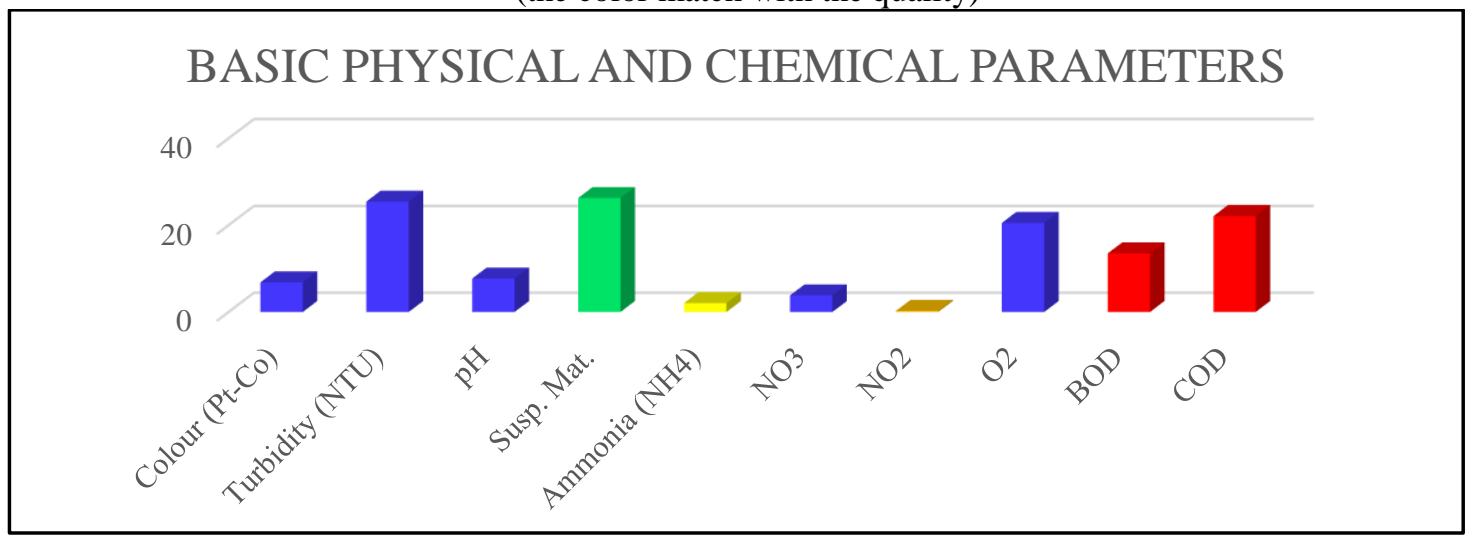

Figure 3. Annual regime of the concentration of heavy metals in the waters of Serava River $(\mu \mathrm{g} / \mathrm{l})$

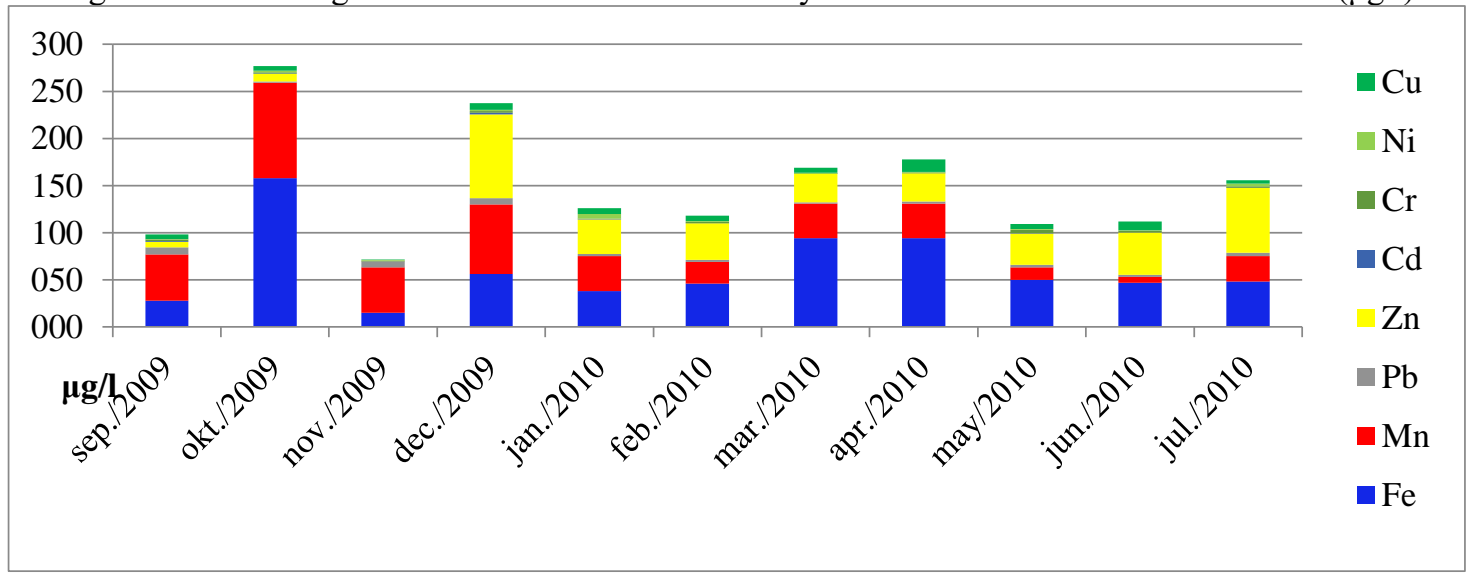

The color as an indicator was determined using a standard calorimetric method cobaltplatinum (Pt/Co). The measuring point in Serava River, before its confluence to Vardar River during the investigated period shows constant values of quality (class I) with an average value $(6,83 \mathrm{mg} / \mathrm{l} \mathrm{Pt})$. Observed by seasons or months, the value of the color never 
leaved the quota for quality Class I, with a small minimal deterioration during the summer months (tab. 1; fig. 2). Turbidity was determined by nephelometric turbidity units(NTU). Turbidity as a form of mechanical water pollution directly affects the dispersion of light, oxygen saturation, photosynthesis and photolysis [2]. Samples of the water before the confluence, demonstrate permanent turbidity of the waters in Serava River throughout the analysis period, with values appropriate to quality class $\mathrm{V}$. The low water quality is kept constant during all months of the year with minor fluctuations during the rainy season when rise and dry period when depreciate. In certain months is noticed increasing of over 100 times above the norms of Class I (tab. 1; fig. 2). The acidity was determined by $\mathrm{pH}$ exponent which is an important factor in many physical and chemical and biochemical processes in the aquatic ecosystems. Particularly dangerous is its low value even in pure water which can lead to the release of heavy metals from sediment [3]. Optimum $\mathrm{pH}$ range of the exponent in rivers range from 6,5-8,0 [2]. In all samples throughout the year in the Serava River the $\mathrm{pH}$ exponent officiate quality class I with an average value of 7,70 (tab. 1; fig. 2). Seasonal and monthly variations are insignificant. Stated condition of acidity is not including the anthropogenic factor for deterioration of quality based on this indicator. Suspended solids, as an indication of mineralization, are usually the result of natural erosion processes. They can very adversely affect the oxygen regime and Photosynthetic processes. In terms of this indicator we can conclude that the Serava River enters in Vardar River with average quality class II with an average 26,25 $\mathrm{mg} / \mathrm{l}$. In most of the monthly samples the concentration of suspended solids hold within the class II, while in April exceeded the norms for quality of class IV (66 mg/l). In the months without rain, with reduced flow, the situation was most stable (tab. 1; fig. 2). From the forms of nitrogen as a nutrient, the ammonium ion $\left(\mathrm{NH}_{4}{ }^{+}\right)$is toxic and unstable form which elevated concentrations reflects the over load of the aquatic ecosystems with sewage, especially if the amount of dissolved oxygen is low. In the waters of Serava River this refers almost permanent concentrations of quality class III-IV (average 2,05 mg/l). The impact of sewage from the settlements in the confluence of Serava River are partially depreciated only in the samples during April, when concentration barely kept within quality class I-II (tab. 1; fig. 2). The input of nitrates $\left(\mathrm{NO}_{3}{ }^{-}\right)$as a form of nitrogen in the water goes through postponement of animal litter, faeces and washing of soil treated with fertilizers [6]. The concentration of nitrates in Serava River during the explored period held within quality class I-II with an average value of $3,82 \mathrm{mg} / \mathrm{l}$ (tab. 1). With such minimal production of nitrate ion, it can be concluded that anthropogenic influence does not exert strong pressure on the waters of the watercourse. Nitrite $\left(\mathrm{NO}_{2}{ }^{-}\right)$is an intermediate product between ammonia and nitrates. Nitrite is a toxic form of nitrogen for wildlife in water at very low concentrations. In the waters of Serava River in Skopje Basin during the examined period they were recorded average annual concentrations of $0,26 \mathrm{mg} / \mathrm{l}$ corresponding quality class III-IV and undoubtedly includes anthropogenic factor for their input through wastewater, agricultural and industrial activities. Increasing concentrations are noticeable during the summer months (July and August) with a reduced flow of the water when they are retained within quality class $V$ (tab. 1; fig. 2). From the forms of the oxygen regime, analyzed were: dissolved oxygen, the biochemical consumption and the demand of chemical oxygen. Dissolved oxygen is an indicator of "health" of the water ecosystem and metabolic processes related to the degradation of existing organic matter [2]. According to this indicator Serava River in Skopje Basin at the confluence features high quality (class I) with an average annual amount of 20,51 $\mathrm{mg} / \mathrm{l}$. The high class quality is kept during the whole year without expressed monthly 
fluctuations, except in July when is referring penetration within class II (tab. 1), which is a feature of the reduced flow and the increased water temperature, which leads to reduced aeration. Anthropogenic impact on the water quality of Serava River is visible through the biochemical oxygen demand (BOD) which indicates the presence of organic matter decomposition that's enhanced consumes dissolved oxygen. So (BOD) in the investigated period was marked by an average annual quality Class IV $(13,50 \mathrm{mg} / \mathrm{l})$, with slight monthly variations when only in July and October officiate quality Class III (tab. 1). Chemical oxygen demand (COD) by $\mathrm{KMnO}_{4}$ is an indicator that reflects the oxygen consumption of total organic decomposition and oxidation processes of metals present in the water. The deterioration of water quality is obvious (tab. 1), and therefore the involvement of anthropogenic factor, so the averages quality reached class $\mathrm{V}(22,9 \mathrm{mg} / \mathrm{l})$. Seasonal and monthly status remains constantly worsened due to the increased concentration of organic materials and metals. Regarding the burden of the waters in Serava River with heavy metals, subjects to review were: iron, manganese, lead, zinc, chromium, cadmium, nickel and copper (tab. 2; fig. 3). These substances are considered toxic in relatively low concentrations to plant and animal life and tend to accumulate in the food chain $[3,8]$. Thus, in terms of the Regulation on classification of rivers in R. Macedonia, annual concentrations in the period September 2009 to July 2010 demonstrate incidental exceeding on the maximum allowable concentrations of fitness for: manganese and copper, with frequent exceed in cadmium (tab. 2, fig. 3). Manganese in water naturally is derived mostly from dissolution of shales and sandstones, and can be consumed through metallurgical activities. In irrigation water it must not exceed a concentration of $0,2 \mu \mathrm{g} / 1$ [4]. Occasional appearing's and elevated concentrations of manganese in the months of October and December correspond to quality Class III-IV. Potential sources of manganese in the waters in Serava River are wastes from industrial activities that are ejaculated in untreated water flow. Namely, at the confluence of Serava River intensive separation is performed on the sand, and also several active and metal processing facilities that will undoubtedly affect wastewater on the recipient. Cadmium is a toxic metal that in nature is very rare. In some rivers in R. Macedonia is naturally present and originating from some certain Paleozoic and Mesozoic rocks [5, 7]. The human factor introduces cadmium into the waters by cement dust, smelting zinc ore, production of batteries and more. As heavy metal cadmium in the river Serava is present anomalously riddle and its origin is natural dissolution of the rocks in the upper part of the drainage basin, as well as industrial facilities in the lower basin. His average concentrations $(0,38 \mu \mathrm{g} / 1)$ correspond to quality Class III-IV (tab. 2, fig. 3). Copper as a heavy metal in aquatic ecosystems is derived from certain minerals (limestone, sandstone), mining and metallurgical activities and excessive use of fungicides in agriculture $[3,7]$. In the irrigation water it must not exceed a concentration of $0,1 \mu \mathrm{g} / 1$. The average value of copper in Serava River at its confluence in Vardar in the analyzed period of $5,99 \mu \mathrm{g} / 1$ indicates that this toxic metal is derived from natural origin and are located within the expected amount for class I-II. In the waters of the river Serava in Skopje Basin once its concentration was increased to a level of class III-IV $(13,37 \mu \mathrm{g} / \mathrm{l})$, which does not exclude the impact of anthropogenic although minimized size (tab. 2, fig. 3) . 


\section{CONCLUSION}

In this paper were studied the waters in Serava River before its confluence in Vardar River in Skopje Basin, whose water resources are used for irrigation, in the area of Butel municipality. The assessment of the water was based on 10 parameters of physicochemical analysis and 8 heavy metals as a criterion for quality that have a significant impact on agricultural production, irrigation conditions. According to the limit values for categorization of watercourses in the Republic of Macedonia was established the water quality (above the maximum permissible concentrations) in tested monthly samples of water flow compared to 6 basic physicochemical parameters (suspended particles, ammonium ion, nitrite, dissolved oxygen, biochemical oxygen demand and chemical oxygen demand) and 3 indicators of heavy metals such as: manganese, cadmium and copper. From the analysis of the basic physicochemical parameters can be concluded that it is a clean, well-aerated water flow which is descending from the mountain routes through residential areas of river course changes quality under the influence of anthropogenic factor. The input of untreated sewage is more than evident in the indicators that reflect the organic load of the water. The continuing concentration of nitrites, biochemical and chemical oxygen consumption, indicate increased presence of organic matter and heavy metals whose decomposition or oxidation enhanced oxygen is consumed, and release harmful gases such as ammonia. Elevated concentrations of heavy metals in the samples which were surveyed in Serava River ranged from casual to occasional appearances (iron, manganese and copper) and occasional to frequent occurrences (cadmium). The lowest concentrations were: iron, lead, zinc, chromium and nickel, where in all monthly samples were found satisfactory levels of quality class I-II. Serava River had shown certain anomalies in terms of concentrations: cadmium, manganese and copper (class III-IV) whose origin is related in part by dissolving minerals from the geological substrate, and more with some industrial activities and the use of fungicides. Apart from the state rules for categorization of the river waters, for comparison were used also some world experiences as a benchmark for accuracy of water used for irrigation. In this context, the use value of the waters of Serava River for irrigation is reduced relative to the 7 indicators of heavy metals ( $\mathrm{Fe}, \mathrm{Mn}, \mathrm{Cd}, \mathrm{Cr}, \mathrm{Cu}, \mathrm{Zn}$, $\mathrm{Ni}$ ) which are showing exceeded concentrations and environmental correctness of irrigation water. In this respect, there is a satisfactory quality only in terms of the lead.

\section{REFERENCES}

[1] Statute for water classification in the Republic of Macedonia, Official Gazette of Republic of Macedonia, No. 18/99, pp. 1165-1173 (in Macedonian).

[2] Pavlov K. The Influence of Natural and Antropogenal Factors on Water Pollution in Tikveš Basin (PhD thesis). 2011, Skopje, Faculty of Natural Sciences and Mathematics pp. 424 (in Macedonian)

[3] Ramani S., Bojkovska R., Pavlov K. Environmental Assessment of Water quality of the River Strumica During the last ten years with Overview on 2008. 2010, Ohrid, Balwoise Proceedings

[4] Karri-Matti V. Direct and indirect effects of iron on river ecosystems. 1995, Helsinki, Ann. Zool. Fennici 32: 317-329 
[5] Pavlov K., Bačeva K., Stafilov T., Vasileski D., Toševska S. Assessment of Toxic Metal Pollution in Some Rivers in the Tikveš Basin, Republic of Macedonia. 2012, International Journal of Environmental Protection Dec. 2012, Vol. 2 Iss. 12, PP. 9-16

[6] Pavlov K., Pavlovski G., Radevski I. River Water Pollution with Heavy Metals in the Hilly and Mountain areas in the Tikvesh Basin. 2013, Skopje, Proceedings of Scientific Conference (in Macedonian with English summary)

[7] Pavlov K., Pavlovski G. ASSESSMENT OF WATER QUALITY AND WATER POLLUTION OF THE LUDA MARA RIVER IN THE REPUBLIC OF MACEDONIA. 2015, Skopje, Proceedings of International Conference GEOBALCANICA DOI: http://dx.doi.org/10.18509/GBP.2015.03

[8] Popov I. S., Stafilov T., Šajn R., Tănăselia C., Bačeva K. Applying of Factor Analyses for Determination of Trace Elements Distribution in Water from River Vardar and Its Tributaries, Macedonia/Greece. 2014, The Scientific World Journal Volume (2014), Article ID 809253, 11 pages http://dx.doi.org/10.1155/2014/809253 